\title{
In the Shadow of Empire: States in an Ottoman System
}

\section{Jonathan Endelman}

\begin{abstract}
What is the origin of the Middle Eastern state? Although social scientists have traditionally emphasized the role of the European colonial experience, especially the British and French mandates following World War I, the late Ottoman era from the Edict of Gülhane in 1839 that inaugurated the Tanzimat reforms until World War I represents a period at least as critical to understanding origins of the state in the region. Certain Ottoman provinces known as Eyalet-i Mümtaze or exceptional/special provinces developed under the aegis of the Ottoman Empire that acquired many statelike attributes without becoming independent polities. Moreover, the nature of the Ottoman Imperial center changed to become more similar to that of a territorially delimited state as opposed to the classic multifaceted polity that had been the earlier norm. These developments resulted in a blurring of lines that had traditionally defined state and empire during the nineteenth-century Ottoman Empire. To illustrate this change, economic, administrative, and political examples are presented from Egypt and Turkey. This comparative analysis will identify ways the evolution of the two states was similar as well as critical differences such as the extent of foreign intervention and the role played by representative assemblies. The formation of imperial states within the empire as well as the transformation of the empire to become more statelike resulted in strong state institutions in places such as Egypt and Turkey that long preceded the main European colonial intervention in the region after World War I.
\end{abstract}

The typical account of state formation in the Middle East runs something like this: Although government officials during the Ottoman Empire installed some modern tools of governance such as censuses, governmental statistics, land surveys, and infrastructure construction, these steps were incomplete. These developments constituted precursors to the construction of modern Middle Eastern states, a foreshadowing of future developments, but not part of that process. Rather, only with the advent of British and French colonialism in the late nineteenth century, accelerating after World War I, did state building begin. Observe how Neep (2012: 20) wrote in his chapter "The Architecture of the Colonial State," "Ottoman government remained sporadic and discontinuous; it was only after the first world war that such strategies of power were intensified as they became concentrated in, and dependent upon, the unique possibilities afforded by the institutions of self-consciously modern Mandatory states." While this description may be accurate concerning Syria, to what extent does it hold true for the region as a whole?

Much ink has been spilled on the colonial state and its artificial nature, with World War I regarded as a kind of big bang for the Middle Eastern state (Alon 2009; Dodge 2010; Fieldhouse 2006). This portrait, while not entirely false, is misleading. More specifically, it refers to only one type of Middle Eastern state, that of more recent vintage, and neglects another that possessed a longer legacy. During the late Ottoman 
era, especially the nineteenth century, a slate of states within the empire acquired effective administrative independence from the center. These included Egypt (Hunter 1999), Lebanon (Akarli 1993), Tunisia (Anderson 1987), Algeria (Clancy-Smith 1997), and Saudi Arabia (Safran 1991). ${ }^{1}$ These will be termed "Tier I areas" for purposes of this study.

Ottoman officials called Tier I areas Eyalet-i Mümtaze or exceptional states to convey the distinction that, while part of the empire, they possessed a level of administrative independence reinforcing their distinctiveness from the center. Ceylan (2014: 20-22) claims these states, with Egypt as the most prominent example, possessed the following characteristics:

The administration of the province was confined to the hereditary dynastic line of the governor, coinage was struck in the name of the Sultan, the troops sent soldiers to support the Empire's forces in war, and the Sultan's name would be mentioned during Friday prayers. In return for these duties, the provinces possessed relative freedom of internal administration and the governor was free to contract agreements with foreign rulers so long as these did not harm the Ottoman state.

In contrast to entities with a developed state apparatus, other areas of the empire had a weaker structure. Termed "Tier II areas" in this chapter, these include Iraq, Jordan, Palestine, and Syria, which were not designated as discrete political entities but featured territories subdivided and led by local notables or ayan. Accounts on the artificial nature of state formation in the Middle East have focused primarily upon Tier II areas, ignoring Tier I areas. While most scholars have concluded that little or no significant state building occurred in the Middle East until after World War I, the Tier I areas contradict this assertion. Histories of individual countries, however complete, cannot afford the perspective required to understand the interconnections elucidated only through regional analysis.

Inherent in the traditional account of Middle Eastern state formation is this: The creation of modern states necessarily involves a process of becoming "like Europe." Mitchell (1991) in his book Colonising Egypt made this assumption focusing on the "exhibition" in which Egyptian reformers are shown to have accepted wholeheartedly the European emphasis on display and visual effect. Similarly, Toledano (2003: 49) described the reforms of Muhammad Ali to "modernize" Egypt (1805-48) that were continued by Ismail (1864-69) as "costly ... extravagant" imitations of Europe. The state here appears not as a native institution, but as a foreign import like Coca Cola or MTV brought to non-European places directly from Europe, as in the colonial state, or in imitation of it. In a study on Hamidian era education, Benjamin Fortna (2002: 1) notes the generality of this viewpoint within late Ottoman historiography: "In an unabashedly teleological fashion, the histories of the period have traced the 'inexorable' processes of Westernization, secularization, and modernization as they began in the eighteenth century, garnered strength in the nineteenth, and triumphed in

1. Saudi Arabia represents something of an exception. Despite the existence of the Wahabbi state starting in 1811 the dynasty never moved to establish a state structure. 
the twentieth." These three trajectories blend, so that modernity becomes synonymous with "the West" and becoming "modern" means becoming "Western."

Academics addressing the colonial state implied it possessed a European character, built with the European initiative on the model of Europe (Sharkey 2003). Postcolonial theorists stressed the European pedigree of the state as well. Chatterjee (1993: 32) indicated ways European notions of the state remained with Indian nationalist figures like Jawaharlal Nehru so that "even our imaginations must remain forever colonized." Postcolonial theorists recognized the problem of these seemingly universal but quite particular categories, but offered few practicable solutions. Attempts to "provincialize" Europe (Chakrabarty 2007) or pleas to dwell upon hybridity (Bhabha 1994) provided little help. If we must operate inside our existing categories of discourse, particularizing the general seems a Herculean task. Yet if we are to work as social scientists, we must have stable and well-defined categories. How can we avoid Eurocentrism while maintaining a stability of the referent when it comes to the word state? Is the state a uniquely European form of governance that other areas copy? What do we mean when we say state?

By observing the development of political governance in a variety of understudied non-European areas, the notion of what stateness implies becomes clearer. In this context, Connell's insistence on the use of "Southern Theories" becomes important. Connell (2007) recognized that, while we cannot discard the existing framework despite its inherent European particularism, scholars may improve upon it by incorporating the subaltern, not only as the object of study, but also as the lens through which we study. To this end, Connell explored some Persian, Indian, and Arabic political theorists incorporating them into the sociological canon. Obviously, all this could not be accomplished in a single volume, but it remains a good start. Thus, we ought not to discard terms such as the state derived mainly from European examples (Anderson 1985; Elias 2000; Tilly 1992). Rather, historical sociologists with expertise in other areas of the world must add examples that yield an empirically more accurate picture of the notion under discussion (cf. Ikegami 1997). This article contributes to this process by incorporating the Ottoman Empire more fully into the picture of state formation.

\section{Case Selection: Egypt and Turkey}

This analysis focuses on Egypt as the representative Tier I areas. Undoubtedly, similar stories could be told for Tunisia, Algeria, and Lebanon. Discussion will generally be limited to Middle Eastern states that developed state apparatuses, including rational bureaucracies with pay scales, hierarchies of job promotion, conscript militaries, and infrastructures like telegraphs and railroads. Both the Ottoman Center and Tier I areas meet these qualifications, whereas Tier II areas do not. ${ }^{2}$ Within Tier I, the primary

2. This is not to imply Tier II areas did not meet some of these conditions. The Hijaz Railway (1908) passed through Syria, Jordan, and Saudi Arabia and was financed entirely by voluntary contributions, due to the dire straits of the empire's finances. 
focus remains Egypt for several compelling reasons. First, as the most populous country in the region, long seen as a regional power, Egyptian state development has been extensively documented. Second, while most Tier I areas experienced growing independence, Egypt's progress was more developed: Thus, any phenomena established will be more prominent. Finally, Egypt had a particular impact on nineteenth-century Turkey so that discussions of Ottoman state development would be incomplete without a concurrent analysis of Egypt.

Within the context of state development, one central question remains: Given that Egyptians and Ottomans both experienced the growth of state apparatus and the beginnings of representative government, why did the latter by the onset of World War I possess a functioning parliamentary tradition under the Young Turks while Tier I entities like Egypt, Tunisia, and Algeria did not? The key difference lies in the fact that Turkey did not undergo foreign invasion experienced by Tier I areas and so was able to develop a working model of parliamentary democracy. These Tier I countries started reform programs focusing on military and bureaucratic standardization designed to catch up with Europe. Over time, these reforms acquired a life of their and came to encompass almost all aspects of the public sphere, culminating with the birth of representative parliaments. In Tier I cases like Egypt and Tunisia, this development was stymied by foreign military invasion, whereas in Turkey it was not. By the eve of World War I, Turkey, unlike Egypt, had a functioning parliament that exercised governing control. Although it lies outside the scope of this project, we can see the fruits of this development based on what occurred in the 1950s. Turkey experienced its first peaceful transition of power from the Republican People's Party to the Democratic Party in 1950, whereas in Egypt Gamal Abdel Nasser inaugurated a dictatorship in 1952.

The growth of state infrastructure and the birth of parliamentary institutions constitute events in a particular sequence. The order of these events is important in that we could not reverse them and get the same result. The growth of state apparatus and the absence of foreign military invasion represent essential measures for developing functioning representative institutions. Only in Turkey did these events occur in this sequence as a necessary and sufficient causes of democratization. Finally, the British invasion of Egypt in 1883 would radically alter Egypt's political future in ways not initially apparent. Although Egypt had experienced foreign economic and diplomatic intervention by European powers, military intervention constituted a more radical step. Although the British may not have intended to implement a formal occupation, the bombing of Alexandria represents a point of no return for British involvement in Egyptian affairs.

In advancing the view that a close relationship exists between halting parliamentary reform and the extent of foreign intervention, mitigating factors must also be weighed. Were democratic developments in Egypt before the British invasion truly significant? Firstly, perhaps the parliament never acquired an independent standing from the monarch, or social, political, and economic factors other than European involvement could explain the disruption of Egypt's parliament. Secondly, in terms of Turkey, if the parliament under the Young Turks worked less effectively than has been 
TABLE 1. Graphical representation of the argument

Indigenous state apparatus None

Direct foreign interference No direct foreign interference
Egypt (strong state, no Democracy) Turkey (strong state, Democracy)
Syria (weak state, no Democracy)

Saudi Arabia (weak state, no Democracy)

Note: Only in the box with an indigenous state apparatus plus no direct foreign interference do we see the result of representative government.

assumed, or if European influence within Turkey was as great as what existed in Egypt, this would represent a serious challenge to the hypothesis that foreign intervention constituted the key variable between these states (Table 1). The first possibility, especially because of the tenuous commitment the Young Turks had toward democracy, remains a consideration. While they came to power professing to restore the Ottoman Constitution of 1878 and reconvene the chamber of deputies to restore the rights of all Ottomans, the Young Turks in power turned to single-party dictatorship advancing an ethnic nationalist agenda (Göçek 2008; Sohrabi 2002). However, a close analysis of the situation in Turkey suggests the maintenance of a parliamentary form by the Young Turks despite their usurpation of effective political power had lasting effects. One of the most important of these consequences being that, after July 24, 1908, sultanic rule was forever ruptured (Göçek 2008: 180).

In understanding why Turkey escaped direct European military intervention when Egypt and Tunisia did not, it is important to note the role of nineteenth-century Ottoman reforms in the construction of the Turkish Republic, which according to the standard nationalist rhetoric rose phoenix-like from the ashes of the defunct empire (Virginia 2005/2006: 19; Kasaba 2006: 219). As Ortaylı (2005: 32) wrote: "The Republic's revolutionaries did not arise in a society stuck in the Middle Ages. They set out on the road from the last Ottoman period with a society in the pangs of modernization from the passing relic of the Territory." 3 The strength of the Turkey, its tradition of militarism, and its democratic success relative to other states in the region cannot be understood apart from this. Although ideologically Ataturk desired an emphatic break with the past, institutions such as the Turkish parliament, army, and bureaucracy owe their roots to the Tanzimat reformers, Young Ottomans, and Young Turks. The idea of the military as "guardian" of Turkish democracy (Altınay 2005), a concept that has precipitated multiple coup attempts, can only be understood with reference to the extralegal measures the Young Turks felt they had to take after witnessing the defeat of the 1905 Russian Revolution at the hands of a politically crafty tsar who overcame his parliamentary opposition. The desire of Turkish officials to control religious groups

3. IIlber Ortayli denounces strongly those academics who recognize the Armenian Genocide of 1915. He admits Ottoman military commanders ordered forced migrations of Armenians, but claims these were justified because of the activities of militant Armenian nationalists who aided the Russians against the Ottomans in World War I. Consulting Ortaylı here to describe certain elements of the Ottoman reform movement in no way endorses his view of the fictitiousness of the Armenian genocide. 
can be traced back to this era. In 1866 the government outlawed the Bektaşi sufi order, the group of preference for the Janissaries, and instituted a Meclis-i Messayih or parliament of religious scholars to bring them firmly under control (Ortayli 2005: 137). This move, although only partially successful, set the precedent for state control over the religious establishment to a greater extent than had previously been the case.

Why specifically did Turkey escape the interference that occurred in Egypt and Tunisia? European powers, especially Britain, fought to maintain the territorial integrity of the Anatolian heartland. When Mehmed Ali's son Ibrahim began his string of military victories against the Ottomans conquering large tracts of the countryside up to Bursa and threatening the capital, Britain intervened because it did not wish to see the empire dismantled and viewed a moderately strong Ottoman state as a buffer against Russia, especially in the Dardanelles (Hanioğlu 2010: 110). Regional peripheral states could, however, be poached safely because this did not interrupt the balance of power. During these years, a careful balancing act occurred where European powers acquired as much land as possible from the Ottomans without tipping over the apple cart. As a result, democratization continued in Turkey but not in regional states like Egypt because of the absence of direct European interference to the same degree as in the latter. While nineteenth-century European officials felt compelled to preserve an intact political entity in Asia Minor, they had no such compunctions about Tier I areas. Indeed for the British, the construction of the Suez Canal and the desire to ensure secure passage to India provided the opposite impulse. British bombardment at Alexandria and the final attack at Tel el-Kabir midway between Suez and Cairo struck a blow against representative government in Egypt from which it never recovered. Although no conclusive proof exists that Egyptian democratic politics would have followed a different path had it evolved unmolested, there is no doubt British military intervention stifled this process.

The fight for an Ottoman constitution and representative government did not face a smooth road. However, in contrast to Egypt where democratization was interrupted by foreign intervention, in the Ottoman instance the sultan derailed the process. After deposing Abdülaziz for his spendthrift habits and opposition to representative government and shortly thereafter deposing Murad V following his nervous breakdown and the suicide of his predecessor, Ottoman constitutional reformers installed Abdülhamid II. Although promising to institute a constitution and parliament, the sultan reneged on his pledge. Instead, his reign witnessed renewed strength for the palace at the expense of bureaucrats at the Sublime Porte who had been dominant during the Tanzimat period (1856-76) (Davison 1973: 403). However, because the country was not occupied by a foreign power, as Egypt would be, constitutionalist forces were able to regroup, gaining control of the state in 1908 .

\section{Imperial States}

One reason regional polities in the late Ottoman Empire have been ignored is because they do not fit into a neat category. They do not represent a colonial state, where an 
outside power fashions a governance structure to control a given area. Neither do they represent nation-states, the modern ideal of political governance where every demos, political entity, has its ethnos, ethnic group or people (Mann 2005). Tier I domains represent neither colonial nor nation-states, but another entity entirely, namely imperial states. In this respect, they constitute regional states within an empire, a phenomenon that has not been described in any other scholarly work. ${ }^{4}$ Their ideological component remains imperial even when their administrative apparatus resembles a state. Given this construct it is possible to challenge the hyphen between the two components of nation-state and disassociate the state as an institution from the nation as an ideal. Moreover, rulers of imperial states felt their countries derived more benefit by remaining within the empire than by leaving it. Thus, despite the fact they could have declared independence from the Ottoman Empire, these rulers did not wish to do so because of benefits they received.

These areas constituted states in the Weberian sense that they possessed "the monopoly of the legitimate use of physical force within a given territory" (Weber 1958: 78). Tier I areas like Egypt, Tunisia, Algeria, Lebanon, and Saudi Arabia contrasted with Tier II areas, where local notables often formed alliances with Ottoman administration, a phenomenon noted by Albert Hourani (1969). This does not mean Tier II entities, including Syria and Iraq, did not possess any features associated with the state, yet they did not practice them to the same extent as Tier I areas and were more dependent on authorities in Istanbul. Tier I areas, in addition to being states, were simultaneously part of the Ottoman Empire: The elite in these countries spoke Turkish and received appointments from Istanbul. Consequently, they constituted states within an empire. Arab nationalist, Turkish Kemalist, and European colonialist narratives have all downplayed the contributions of the Ottoman Empire to state formation.

However, an objective look at the historical record reveals that empire and state coexisted and became entwined in the same Bourdieusian field of late-nineteenthcentury Ottoman politics (Bourdieu 1993). Regional states expected a degree of support from the Ottomans against European invasion to guarantee the Islamic social and political order, a tall task given that the imperial center was facing many of these pressures. At other times, these states resented measures the center forced upon them. Under the treaty of Balta Liman signed between the British and Ottomans, all internal taxes on imported goods by foreigners were abolished (Marsot 1984). This proved disastrous for the nascent Egyptian manufacturing industry as it stimulated an influx of cheap British merchandise into the area and dismantled Mehmet Ali's monopoly system. Although detrimental to industry, the Egyptians were forced to accept the treaty following their defeat by an Anglo-Ottoman force at Acre in 1840.

Not simply one country but several came to occupy this middling position between independent countries and provinces of the empire. What appears especially intriguing to the modern observer is which activities the Ottomans considered a treasonous rejection of authority and which they tolerated. Mehmed Ali defeated two Ottoman

4. Cooper (2005) tries to show how metropolitan states depend on their empires. I am trying to show how regional states depend on metropolitan empires. 
governors sent to rule Egypt after having recovered it from the French through a joint Anglo-Ottoman invasion. Afterward they had no choice but to appoint him governor, which is surely what he wanted all along (ibid.: 50). Rebelling against Istanbul, a practice modern analysts would see as treason, constituted a traditional practice in the Ottoman Empire for gaining regional power dating back to the sixteenth century (Barkey 1996). In contrast, seemingly banal minutiae, such as what the language of administration would be, symbolized salient political details. Mehmed Ali understood Arabic, but refused to speak it, preferring strictly Turkish (Marsot 1984: 97). Likewise, while dreaming of creating an Egyptian state, and even an empire, he never denied the sultan's authority. Even during the nationalist revolt in 1882, the leader Ahmed Urabi constantly asked the sultan for support, describing himself as the sultan's servant, though rebelling against the sultan's representative in Egypt (Schölch 1981: 231). Determining exactly what constitutes a rebellious act, what does not, and why remains a fascinating phenomenon.

As a result, we may say that Egypt and Tunisia were ruled by men who were functionally independent, culturally Ottoman, and ideologically split. Despite growing independence, Egypt remained part of the empire and considered itself as such. This tension between Egyptian independence in the political realm and dependence in the cultural and symbolic one underlay the Urabi revolt of 1882. Why did this dichotomy persist? Why did Egypt remain an Ottoman province despite its ability and desire to be independent? Although we cannot know for certain, James Scott's concept of a distinction between public and hidden transcript (1992) may prove illuminating. Egyptians professed to be loyal Ottoman subjects in the public transcript because this was culturally acceptable, yet behind the scenes tried to grab as much power as possible even at the expense of their supposed suzerains.

Rulers of regional states often exploited ambiguous situations by looking for ways that could jointly benefit both the empire and themselves. One tactic they tried was assembling large armies. The Ottomans often requested help from regional armies in their campaigns. The dispatch of Egyptian troops to aid the Ottomans in the Crimean War of 1853-56 is one such example (Toledano 2003: 85), as was the decision by Mehmed Ali to send troops to Morea to suppress the Greek Revolt (1821-32) to which the Bey of Tunis also contributed forces (Fahmy 2011: 55). However, on other occasions, Egyptian rulers camouflaged attempts at territorial expansion in the guise of helping the Ottomans. For example, Mehmed Ali responded favorably to the request by the Ottomans to crush the rebellious Wahhabi-Saudi forces in 1818 because he wished to annex the Hejaz to control the lucrative Red Sea trade (ibid.: 44). Regional rulers constantly sought to improve their position vis-à-vis the center yet remain within the imperial fold.

We should view the state and the empire as a field in which cultural, political, and economic policies were borrowed from one context and implemented in another. Tier I areas often adopted the same reforms as the center, and in some cases served as models for the Ottomans. The decision by Mahmud II to massacre his Janissaries in 1826, removing them from the political scene to make room for the neziam-1 cedid or "new order" troops formed by Selim III (1789-1807), echoed an earlier 
move by Mehmed Ali in 1811 Cairo where local Mamluks were invited to a banquet and slaughtered (Hanioğlu 2010: 112). Mehmed Ali adopted a monopoly system for all commodities similar to that in the empire hoping to cut out the middle man and fill government coffers (Marsot 1984). Both the Young Ottoman (Mardin 2000: 191) and Young Turk activist (Sohrabi 2011: 55) circulated regularly between Egypt and Istanbul. Mustafa Fazil, the Khedive Ismail's younger brother, served as chief financial backer of the Young Ottomans enabling them to publish their newspaper, the Muhbir, in Paris. He later wrote a letter, widely distributed in lithograph, to Sultan Abdülaziz demanding the creation of an elected parliament and a constitution, comparing the Ottoman situation to that of pre-1789 France (Davison 1973: 204). Moreover, evidence suggests revolutionaries from Egypt's Urabi revolt (1883) knew about the French occupation of Tunisia three years earlier and tried to avoid a similar fate without success (Schölch 1981: 159). Thus, what we see in the Ottoman Empire is the creation of an interconnected network where ideas, people, and institutional models flowed from the center to the provinces, but also from one province to another.

If the view from the edge consists of a province trying to gain more autonomy from Istanbul, the view from the center displays an empire adopting a defensive posture, trying to hold onto what it still possessed. Ottoman historians have had difficulty understanding exactly what occurred in the empire during this period as well as how to describe it. Although this era has classically been labeled one of decline, Karen Barkey in her work Empire of Difference (2008) stresses the Ottomans generally adopted techniques enabling them to maintain flexibility and adapt to changing circumstances. In terms of the Tanzimat period of reform, Barkey voices a different tone, claiming the Ottomans "lost their Empire and the best of what they possessed: their diversity, ingenious flexibility, and resiliency" (ibid.: 3). Barkey displays in detail how the Ottoman system of administration before the nineteenth century allowed for differences while maintaining some degree of control through the hub-and-spoke system where provinces were connected vertically with the center but not horizontally with each other.

At one level, Barkey is right. The rise of nationalism in the Ottoman Empire in the nineteenth century often made it less accepting of religious and cultural difference than previously. Yet Turkey was one of the last countries where ethnic based nationalism surfaced (Davison 1979: 26). The thesis written by Yusuf Akçura entitled Üç Tarz-1 Siyaset (1912) constitutes the first time the idea of a Turkish union appeared in Ottoman history (1976: 9). The appearance of a specifically Turkish type of nationalism constitutes a tacit admission that efforts by officials to preserve the empire within an Ottoman framework were failing and a new path was needed. Agreeing with "Caliphates and Juntas," this chronology places the emergence of Christian Balkan nationalism in the nineteenth century before the development of predominantly Muslim polities such as Albania and Turkey in the early twentieth.

The divisiveness Barkey identifies came from minority groups separating themselves from the empire rather than groups being pushed out by the Ottomans. The Ottomans tried to prevent this by being more inclusive rulers. Furthermore, it is possible to take the opposite view that the empire was more accepting of difference than at any 
other time in its history. Whereas before being Ottoman, Osmanlı meant quite literally that one was "of Osman," or belonging to the House of Osman and exempt from taxes, in the nineteenth century the meaning changed to something approaching citizenship. ${ }^{5}$ Witness article Eight of the Constitution of 1876: "All subjects of the Empire are ... called Ottomans without distinction to the religion that they profess" (American Society of International Law 1908: 368). Yet the Ottoman citizenship movement cannot be viewed as completely successful because it failed to deliver on many promises, especially improving the lives of the peasantry vis-à-vis the landlords or establishing equality between non-Muslims and Muslims. Salzmann notes, "Despite fiscal reform local lords continued to impose illegal dues on peasants and Christians and Jews were still subject to forced conversions" (1999: 45). Given the deeply entrenched interests in the old system, any attempt to radically alter it would necessarily encounter resistance from landlords and tax farmers whose status was threatened (Inalcik 1976). However, despite its fleeting nature, Salzmann asserts, "The Ottoman reform movement deserves recognition as one of the most significant examples of nineteenth century liberal franchise" (1999: 56) in comparison to similar European movements at that time. This shift toward a common Ottoman identity became a pervasive ideology among statesmen such that "the Empire's cosmopolitan culture was Ottomanism" (Ortayl1 2005: 141). Officials tried to incorporate disparate groups under a common Ottoman identity that established formal equality among all members.

Two concepts discussed here, toleration and inclusion, deserve more consideration because of their multivalent nature in contemporary political discourse. The tolerance of the Ottoman system is described by Aron Rodrigue: "Difference was given and accepted as such" so that "groups did not necessarily have to share similarities to have a place in the overall arrangement" (1995). Tolerance, however, did not mean equality. In the Ottoman system, a definite hierarchy of religious groups existed, with Muslims occupying the apex of the pyramid. Yet, unlike modern nation-states, the Ottoman government did not often exert pressure on non-Muslim religious or ethnic groups to assimilate to the dominant group nor did they exclude them. Periods of religious persecution were not unknown, yet these remain the exception to the general rule of an accommodating stance toward religious differences. Rodrigue (ibid.) notes that Jewish and Christian leaders did not need to struggle for their existence because they knew they were tolerated. Leaders arranged the affairs of their own communities in return for maintaining stability and pledging loyalty to the Porte. This system appears remarkably similar to one given to the semi-autonomous provinces, which should not come as too great a surprise because until 1878 "the Porte dealt with the millets through the ministry of foreign affairs as if they were separate nations" (ibid.: 33). The inadequacy of this arrangement became apparent to officials as they realized a stronger statelike structure was necessary to compete militarily, economically, and diplomatically.

5. My thanks to Yale Turkish instructor Etem Errol for this point. Fortna (2002: 176) calls Ottoman school children at this time "subjects and proto-citizens." 
Repression through violence, the stick side of the Ottomanist carrot, also occurred when the Ottomans suppressed the Bulgarian revolts of 1876 using the army and irregular troops, or başıbozuks (Millman 1980). Known as the Bulgarian Massacres, this created a sensation in the European press. Similar incidents occurred in 1832 when the Ottoman army invaded Morea in Greece in 1832, in 1860 when a group of Druze massacred Maronite Christians in Lebanon, and in Crete in 1866-69 (Fawaz 1994; Rodogno 2011). In Morea and Lebanon, the French intervened to prevent widespread killing. However, in both Bulgaria and Greece the Ottomans sent armies to suppress rebels because of the actions they took, not because of who they were. As Michael Mann (2005: 32) notes, "Ethnic cleansing is an essentially modern phenomenon" that occurs because the majority ethnic group sees the minority ethnic group as a threat to the nation. Such an ethnic conception of the nation gained currency after the failure of the ideologies of Ottomanism and Islamism and the rise of Turkism that eventually morphed into Turkish nationalism. During the period here (1826-78), however, the Ottoman polity was still defined in territorial, demos, terms instead of ethnos, ethnicnational ones. Violence to crush rebellions was aimed at eliminating a geopolitical threat, not at eliminating a people.

Instead of lamenting a loss of flexibility due to centralization that occurred as a result of the Tanzimat, more attention should be paid to how outside influences interacted with inside cultural patterns to produce novel notions of governance, particularly in local contexts. As Mardin (2000) noted, the impetus behind the Tanzimat reforms did not materialize out of thin air but constituted an attempt by the empire to adapt to radically changing circumstances: "The shock experienced by the Empire when they realized ... the Empire was declining and especially the trauma caused by the continuous reverses ... they suffered in the late eighteenth century was a very severe and painful one" (ibid.: 135). Another insight can be gleaned from a distant country also experiencing a series of painful adjustments. Go (2008) in his book American Empire and the Politics of Meaning noted how Puerto Rican officials were forced to undergo a painful process of revision because traditional ways of engaging in patronage politics were frustrated by changing situations, while their Philippine counterparts did not do this because their conceptual schemas still worked. A similar process of reformation of conceptual categories to accommodate new information occurred for Ottomans in the late nineteenth century. What changed was not only what Ottoman officials thought, but how they thought it, similar to the Puerto Rican case.

Rather than describe the process as one of Ottoman decline or European imitation, terms carrying value-laden connotations and inherent distortions, a more fruitful approach can be found in the concept of "fusion," a view similar to that advanced by Mardin (2000: 8) who stresses the impact of "local Turkish developments that were only indirectly the product of Western influences" and by Fortna (2002: 45) who speaks of "a fusion of the exogenous and the indigenous that reflected both global trends and the particular dynamic inherent in the Ottoman predicament." Similar to a chemical reaction when adding one compound to another to produce a third in the laboratory, Ottoman and Egyptian states must be seen as the admixture of local context with foreign ideas producing a third element, the fusion that incorporates both but 
fully encapsulates neither. Local innovators endowed familiar concepts, like ümmet (Turkish) or ummah (Arabic), "the people," with new meanings, creating neologisms where none existed, such as serbestiyet, which the Young Ottomans coined as an analog for liberte from serbest, meaning free (Mardin 2000: 189). Hence, a greater degree of agency is bestowed on individuals, who become creative agents of change as opposed to passive recipients of it.

The integration of this Islamic discourse into that of constitutionalism constitutes one of the most fascinating instances of how fusion occurred. Mardin (ibid.: 250) notes the Young Ottomans were the first to introduce notions associated with European positivism including progress and rationality to the broader public, and to synthesize these elements with Islam. The Young Turks, despite their avowed secularism, adhered fairly strictly to the Islamic line that the constitution and parliament represented not only the best, normatively preferable, and scientifically effective means of governance, but one accorded with the tenets of Islam (Sohrabi 2011: 61). In the Ottoman, Egyptian, and Iranian cases, the commands for consultation, shura (Arabic) or meşveret (Turkish), of the just Islamic ruler with other experts as well as adalet, justice, served as the basis for parliamentary democracy (ibid.: 81, 40).

What makes these reforms fascinating was neither their importation of liberal European institutions, nor insistence on local particularism, but rather the ability to craft a middle road between the two. Davison (1973) has said that historians who accuse the Young Ottomans of going too far in the process of reform or not going far enough miss the point. They fall into historical fallacy, disregarding "the necessity for both change and continuity in history, for doing what is possible, for grafting the new onto the old" (ibid: 405) because change must be seen in light of possibilities open to individuals experiencing the events. From this perspective, state building and democratization reforms in Egypt and the empire, though timid by today's standards of liberal democracy and open to criticism due to numerous deficiencies, constitute revolutionary departures from past practice. Moreover, modern scholars must remember both movements represent cumulative processes. While certain historical events create certain possibilities and foreclose others, they leave open the door of historical contingency.

By employing concepts like imperial states and fusion, scholars can begin to identify positive, empirically accurate, and value neutral descriptions of what occurred during this period. Moreover, while helpful in noting differences that accompanied direct European rule, earlier studies of colonial state construction in the Middle East have systematically underplayed the development of an indigenous state position and the degree of influence European countries had on states before they formally invaded. What is required is an approach incorporating both the Ottoman Center and regional states while acknowledging European influences. Although two entities will be considered in detail here, namely Egypt and Turkey, a similar story could be told for Tunisia and Algeria.

Although this approach stresses indigenous development, it would be impossible to deny both the Ottomans and Egyptians viewed Europe as the model of the state they wanted to build. Local bureaucrats saw Europeans as standing at the cutting edge 
of statecraft: They modeled local institutions after what they saw as more progressive ones. Yet both Egyptians and Ottomans had to shield their polities as much as they could from the increasing tide of European influence. Ironically then, the Ottomans and Egyptians had to rely upon Europeans for technical, financial, and administrative assistance, while still recognizing the political threat this posed for local governance. The introduction of cash crops, including cotton, seemingly brought a tremendous boon to the Egyptian economy raising the level of living for the elite and peasants, although more slowly for the latter. However, cotton made Egypt more dependent on Europe for its trade and caused the number of European merchants in Alexandria and Cairo to skyrocket (Owen 1969: 113), augmenting European pressure on the Egyptian government and undermining local control. Ultimately, the Egyptians remained stuck between a rock and a hard place with both Europeans and Ottomans suspecting their motives, a phenomenon that created an alliance of strange bedfellows as when the two joined forces to defeat Mehmed Ali.

The need to rely upon European expertise for technical knowledge was not confined to Egypt. James (1989) in The Black Jacobins noted that Toussaint L'Ouverture relied on French and mulatto experts for technical aid regarding plantation agriculture on which Haiti depended even after his revolt against France, 1791-1804. Eventually, this aroused the suspicions of other revolutionaries who distrusted L'Ouverture, leading to his arrest, deportation, and death. A certain amount of borrowing from Europe appears inevitable for those countries that centralize and industrialize later. However, Egypt had strong resources upon which to draw, thriving agriculture, and a large population. Therefore, viewing the growth of the Egyptian state as simply copying a European archetype would be shortchanging the ingenuity required of men like Muhammad Ali. Applying the term state to this process gives a false impression of uniformity with the same institution existing in the European context. While the name state may be the same, the meaning differs depending on the context: It should not be viewed as a carbon copy of the same institution that arose in a different historical trajectory.

Several caveats exist before proceeding too far with this argument relating to democratic developments. First, elections to the Egyptian chamber required a certain amount of property to vote. However, contemporary observers stated the election of 1882 was free and fair within the confines of the restricted electorate. Elections occurred in two stages and were restricted to male property holders (Schölch 1981: 215-16); individuals judged as influential in their communities would represent the desire of peasants under their protection as clients. At no point did fellahin leave their farms and line up at the polls; people who voted, the village shaykhs and guild masters, were men of means. However, the prospect of a restricted franchise followed by wider participation constitutes a not uncommon pathway to democracy. As in England, which possessed property restrictions until the Reform Acts of 1832 and 1867 (Stokes et al. 2013), and in America, which prohibited women from voting till 1920 and African Americans from fully exercising this right until 1965, the pathway to full democracy constitutes a long road. While strong conservative elements in Egypt would have made female suffrage difficult, women paid an active 
role in the nationalist movement of the early twentieth century especially during the much-heralded women's protest of 1919 (Baron 2007).

\section{Bureaucratic, Economic, and Military Considerations}

The development of the imperial state and the viability or failure of democratic initiatives cannot be seen in isolation. Any comparative analysis of Turkey and Egypt must consider the bureaucratic, economic, and military factors influencing the nature of the state and sustainability of reform. Politics does not stand in a vacuum, and only by placing these wider trends in Egypt and Turkey side by side to consider how they resemble one another and how they differ can their divergent outcomes concerning democratic development be appreciated. Economic and bureaucratic developments of the late nineteenth and early twentieth century remain a key component in this analysis, especially in terms of European colonization. Many factors equally affected Turkey and Egypt, and other Tier I entities like Algeria and Tunisia. As regional states became economically prosperous and devoted more revenue to cash crops, they diverted trade away from Istanbul and toward Europe. Concurrently, they embarked on a public infrastructure bonanza with roads, canals, and dikes as governments wished to make their countries more legible in Scott's sense of that term (Scott 1992, 1999): able to be penetrated more easily by officials. Regional governments accumulated debt and investments from Europeans, who lent money to them and bought raw materials. European influence over these countries grew precisely because their infrastructures developed and their economies expanded. To govern efficiently and extract more taxes, autocratic rulers established parliamentary bodies, which acquired an independent existence beyond what their creators intended. As a result, these developments fed into one another and generated the perfect storm for European intervention, processes this article will examine.

Both the Egyptians and Ottomans suffered bouts of currency depreciation (Davison 1973: 18; Owen 1969: 29n1), leading to the failure of paper money (Davison 1973: 350; Ortayal1 2005: 35) and a preference for foreign currency. ${ }^{6}$ Similarly, salaries for civil and military officials were often in arrears, a more serious problem with the latter because they possessed guns. Foreign debt especially to European banking houses occurred in Egypt in 1873-83 and for the Ottomans in 1854-76, known as the "first borrowing period" during which the Ottomans signed 15 external borrowing agreements (Ozekicioglu 2010). Both became bankrupt the same year-1876-with Egypt's declaration following the Ottoman's by seven months (Owen 1969: 122), and both had European Commissions on Debt to reorganize finances and collect debt that creditors felt was owed to them: In Egypt this was known as the Caisse de la Debt and in the Ottoman case it was known as the Public Debt Administration. Both attempted to industrialize to improve their balance of trade, yet largely failed (Marsot 1984: 166-86; Quataert 1993). Thus, economic development brought developed countries

6. Ortayalı (2005: 135) notes the first banknotes were not printed but handwritten. 
of the region more tightly into the European orbit. It is no coincidence that the three earliest countries to be colonized in the Middle East-Algeria, Tunisia, and Egyptall occurred in places designated Tier I areas.

While both Egypt and Turkey experienced European economic encroachment, one key difference helps explain later developments: the impact cotton had on Egypt. For Egypt, cotton was the key. Here the work of Immanuel Wallerstein (2011) on world systems provides a useful way to understand what occurred. At the beginning of the nineteenth century, Egypt and other imperial states were relatively unconnected from the European world system; by the end of it, they had effectively become part of the periphery. According to Wallerstein, the periphery of the world system served as the place where core countries extracted their resources and to which they exported their products in a mercantilist schema. As Egyptian trade redirected to Europe and European merchants became more involved in its interior, European political influence increased. Wealth flowing into the country as a result of cotton gave the Egyptian government resources for political control, but it was unable to maintain its system of monopolies. Increasingly, Egypt became a farm for European cotton, the profits of which slipped away from the government and toward European merchants in Alexandria.

Although oriented toward the Ottoman market through its production of wheat, cigarettes, cloth, and cotton in the early nineteenth century, Egypt's balance of trade shifted toward Europe (Owen 1969: 158), particularly with the introduction of long staple cotton. The first variety, Jouvenel, named for the French advisor who introduced it, became wildly successful, transforming the Egyptian economy from 1820 on (ibid.: 45) as cotton and cash crops like silk, flax, and indigo replaced wheat as the main source of income. Concomitantly, a system of private property developed. Originally, the state, and by extension the ruler, possessed complete ownership of land, and the peasant held only usufruct rights. Gradually, land became reclassified as personal private property with deeds, registration, and cadastral surveys to enable the process (Baer 1962). As taxes increased, peasants fled their properties or had lands subdivided under laws of inheritance. The wealthy could avoid this by endowing their lands as family waqfs, or charitable endowments in which their descendants served as beneficiaries, but the poor were originally prohibited from doing so (ibid.: 6). Thus, similar to Brenner's account of the dispossession of English peasants, land became concentrated in the hands of rural notables (Aston and Philpin 1987).

Extensive public works projects such as the building of the Mahmudiyya Canal from 1817 to 1820 and the Suez Canal and the Cairo Alexandria Railway in 1856 put the government in debt. Under the iltizam system and the $u$ hda arrangement replacing it, individuals bid on the right to collect taxes (Marsot 1984: 157). The government proscribed a set amount of revenue for each unit, above which the individual possessing tax-collecting rights could earn a profit. Predictably, this system lent itself to abuse because the holder of the commission had an interest to extract as much revenue as possible. Moreover, taxes on land worked by fellahin, which produced lesser-quality cotton known as kharijiya, were lower than on lands belonging to notables who received it as government grants, known as ushuriya, so called for the tithe or ushr levied upon it (Hunter 1999: 208). Taxes fell most heavily on peasants, who were 
least able to pay, while notables received preferential tax treatment in exchange for political support.

Needing an infusion of quick cash, Egypt passed a law known as the Muqabala, whereby individuals owning ushuriyya land could have their taxes set permanently at half the normal rate if they made a one-time payment to the government of six times that amount (ibid.: 39). Although this created a short-term infusion of revenue to a government short on funds, the system was detrimental to long-term interests because future revenue was lost. Given the expanding public works and inefficient taxation system, Egypt's government experienced fiscal shortages. Rulers of Egypt took out loans from English banking houses, in 1862 from the House of Oppenheim (ibid.: 173) and in 1879 from the House of Rothschild (ibid.: 205). As a condition of the latter, the Khedive Ismail was forced to mortgage his estates known as al Daira al Saniya, which constituted 22.2 percent of arable land in Egypt (Owen 1969: 271). When Egypt declared bankruptcy in 1876, a commission was formed to consolidate debt-Caisse de la Debt Publique (Hunter 1999: 183), while British and French representatives were included in the cabinet: Rivers Wilson, Minister of Finance, and Marquis De Clerc, Minister of Public Works (ibid.: 203). This signaled the end of effective Egyptian independence and the beginning of British dominance. Although it took the Urabi revolt to precipitate a British invasion, the die had already been cast.

This same period witnessed a reform of the military and replacement of the old guard with the new, developments strengthening the Egyptian and Ottoman state despite European inroads. As previously mentioned, the Ottoman Sultan Mahmud II slaughtered the Janissaries in 1826, which resembled a similar move by Mehmed Ali in 1811. The Ottoman Sultan brought European military advisors to drill his New Army in the same way Mehmed Ali had done. However, Khaled Fahmy (2002) noted the Egyptian army proved superior to the Ottoman, because of the leadership of Ibrahim, Mehmed Ali's son, plus the increased use of European officials as officers. Moreover, Mehmed Ali's massacre killed more Mamluks than Mahmud's did Janisarries; in the latter case the old guard remained more of an obstacle (ibid.: 271). Thus, Mehmed Ali was able to create a new army more easily because he disposed of the old one more effectively.

How did the two processes of military reform compare? When Mehmed Ali sent his son Ibrahim into Syria in 1833 to conquer territories, the Egyptian armies defeated the Ottoman troops repeatedly. After the suppression of the Janissaries in 1826, the Ottoman army was quite weak. One Ottoman historian observed that, compared to Turkish troops, the Egyptians had superior organization: "Against Mehmed Ali the forces that went out were mostly untrained and even the officers were ignorant of battle techniques" (Uzunçarşılı 1983: 29). Gradually, Egyptian forces occupied Syria, a large section of Anatolia, even threatening the port of Izmir. Ibrahim, who wanted to advance further and possibly capture the capital, grew impatient with what he perceived as his father's excessive caution. He commiserated, "I wait impatiently for my father's order. I will institute whatever course of action according to his orders. If he says so, I will advance. If he says so, I will retreat; now I am already sick of these Izmir events that I must not mention" (ibid.: 29). Eventually, these advances 
prompted the British, hoping to preserve Ottoman territorial integrity, to help push Mehmed Ali's forces back to Egypt. As a consolation prize, the Ottomans promised Mehmed Ali the right of hereditary succession for the eldest male member of his family, a privilege granted for the first time to a Muslim ruler in the empire.

Perhaps the most transformative process in the nineteenth century was the formalization of bureaucratic channels, particularly in Turkey. As such, the staff of the ruler's house grew into a modern bureaucracy on par with those of Europe. For instance, as Findley (1980: 50) showed, the Bab-l Ali or "Sublime Porte" began as an extension of the sultan's entourage with such offices as "affixer of the royal seal," "chief of ceremonies," and "head scribe" gradually evolving into a cabinet with ministers heading departments. In this context the Chief Scribe became the Foreign Minister, the Chief Bailiff the Minister of Justice, the Chief Treasurer the Minister of Finance, and the Grand Vizier the Prime Minister (ibid.: 140). Additionally, permanent Ottoman embassies with ambassadors were established in several European countries. (ibid.: 118; cf. Göçek 1987).

Egypt was not immune to pressure. Several scholars claimed the bureaucratic and military reforms of Mehmed Ali, the vali or viceroy of Egypt, were more far reaching than those in Istanbul (Hanioğlu 2010: 7; Mardin 2000: 39). Similar to the Ottomans, the Egyptian bureaucracy, begun as an extended household service for Mehmed Ali, expanded to include technical expertise on topics like public health, statistical analysis, and educational policy (Hunter 1999). The Egyptian government created a police force, regulated the possession of firearms, and cracked down on speeding carriages causing traffic accidents (Toledano 2003: 167). These measures portray a government in control of its territory and able to perform its functions of protecting the people as a pastor does his flock as described by Foucault (1998).

Bureaucracies in Egypt and Turkey became more rationalized with payment of taxes and salaries purely in cash, instead of cash and kind or cash and land, and with pensions for government officials during their old age. In Egypt, this pension, originally paid in land, gradually reverted to cash. Both bureaucracies became more interested in statistics and created organizations to collect them (Findley 1980: 286; Hunter 1999: 49) with increasing emphasis on employees' technical knowledge (Findley 1980: 262). As individuals needed proper training for jobs, state schools offered courses for engineering, war, and civil service (ibid.: 125; Hunter 1999: 93).

In addition to possessing comparable bureaucracies and strong autocratic rulers, the two countries developed similar processes of neopatrimonialism. This especially occurred in the reigns of Ismail (1863-79) in Egypt and the Ottoman Abdülhamid II (1876-1909), when each ruler emphasized ceremony to enhance royal prestige and the bestowal of favors on various individuals (Deringil 2011: 35; Toledano 2003: 51). Finally, both attempted to maintain a rational bureaucracy while reinforcing ties of personal dependence (Findley 1980: 353; Schölch 1981: 80). The Ottoman Sultan also appealed to his religious role as caliph, or leader of the Islamic ummah (community), although this was not an option for the Khedive whose position lacked religious underpinnings. In both instances, tension existed between bureaucrats who embraced rationalization and a ruler who embraced reform, but on his own terms. 
The path toward bureaucratization and democratization in Egypt and Turkey bore a strong resemblance to France. Alexis de Tocqueville (2008 [1856]) noted in The Ancien Regime and the French Revolution that the extension of the French state into the countryside and the strengthening of bureaucracy occurred in the last decades of the monarchy. Ariel Salzmann (2004) draws interesting comparisons between the French Revolution and the pre-Tanzimat Ottoman polity regarding financial difficulties and the monarch's struggle to centralize against the wishes of provincial notables. The revolutionaries turned the method of selecting state officials into a democratic process, but left state machinery in place and even strengthened it. Thus, the creation of state machinery and rationalization of the bureaucracy in France took place before the institutionalization of democratic politics. Similar to Old Regime France, the rationalization of the bureaucracy and extension of state power preceded and even precipitated the move toward democracy. For example, in 1845 Sultan Abdulaziz invited two representative members to join the Meclis Ali-yi Tanzımat or High Council of the Tanzimat, a body drafting legislation. The Tanzimat served as an impetus for greater democratization and motivated the Young Ottomans who sought to stem what they saw as the dictatorial path of Tanzimat reforms (Mardin 2000: 115). Because of the check on industrial development, the lower bureaucracy adopted the role of political opposition the bourgeoisie played elsewhere (ibid.: 168). Therefore, the struggle for democracy occurred largely as an interelite affair at the top instead of conflict from a rising middle in alliance with the bottom against the top as in France (Moore 1993). Democracy and constitutionalism for Ottomans and Egyptians represented a symbol behind which leaders of opposition movements, the Young Ottomans and Young Turks as well as Urabists, could gather support. The Young Ottomans drew their support from the lower ulema, or religious scholars, the lower and middle bureaucrats, and the military (Mardin 2000: 220).

What did these groups have in common? According to Mardin, all of them were frustrated by blocked career paths. Because of the growing power of upper bureaucrats who took over functions of governing from rival power groups including the sultan, these individuals lost professional standing. They consequently rallied behind constitutionalism to pressure upper bureaucrats to preserve their status. The accusations of despotism and desire for more democratic processes were directed as much if not more against these bureaucrats than they were against the sultan. Scholars note the slow pace of advancement for native Egyptian army officers compared with their turcophone compatriots motivated constitutional and parliamentary demands (Cole 1992: 221). Thus, because of the political zeitgeist in vogue in the aftermath of the French Revolution (Sohrabi 2011: 6), constitutionalism represented a banner to rally those with common grievances against the administration in power.

\section{Explaining Similarities}

Why, despite their divergent objectives, did the means the two used appear to be so similar? Officials at the Porte wanted to curb the autonomy of those at the periphery 
and subsume areas firmly under central control. By contrast, regional elites wished to accumulate for themselves and their nascent administrations as much freedom as possible. Despite this, those in the center and at the periphery pursued nearly identical reforms to achieve these goals. In other words, the destruction of the Janissaries, the introduction of uniforms on European models and drills with precision movements, the creation of cabinets headed by ministers, the separation of the ruler's household from the state administration, the secularization of the government, the reassertion of the ruler using patrimonial tools of personal dependence, and even the development of representative bodies of notables occurred in nearly the same fashion in both instances. Why do we witness nearly identical processes among groups with conflicting desires?

First, as earlier stated, both Egypt and Turkey belonged to the same Ottoman field where ideas, people, goods, and money traveled from one place to another. Both countries occupied the same structural position in the world economic system. It makes sense that the two follow similar economic trajectories of debt, borrowing, and bankruptcy. Finally, ideologically both Ottomans and Egyptians imbibed the potion of positivism permeating their contemporary world in the Ottoman Empire, its tributary states, and Europe. Terms like civilization and progress became buzzwords possessing an almost talismanic power. Those countries with aspects of "civilization" including strong state administrations modeled after France and strong parliaments modeled after England would succeed, both economically and politically (Davison 1973: 363). Devices such as world's fairs were popular during this period to confirm ideologically and visually that your nation had "made it." Thus, both the Ottoman and Egyptian states spent considerable money on displays for world's fairs, expositions, and public schools (Deringi 2011: 156-62; Fortna 2002: 90).

If parliamentary democracy represents a convenient tool for advancing certain groups who have "lost out" or to imitate successful countries, could it have a lasting impact on politics? In other words, if parliament or a constitution represent nothing more than a kind of ideology used to justify a move to rectify the distribution of resources, as posited by resource mobilization theorists, are these items merely window dressing? As stated in another article about the impact of the cult of the monarch in Jordan (Author 2015), symbols unleashed into the public sphere often acquire a life of their own. While ideology may be incidental to the motivations behind revolutionary movements, as argued by Skocpol (1979) and Goldstone (1993), these ideologies have a decidedly greater impact in terms of what follows. Symbols, in other words, never remain simply symbols. Although the Khedive Ismail did not intend to create a rival power source when he instituted the chamber of deputies in 1876, this institution would from 1879 to 1882 be a great source of consternation for him. Despite the tumultuous start parliaments had, the incubation period in Turkey relatively free from external molestation engendered conditions more favorable to its development than the European interference created in states like Egypt. Although the First Ottoman Parliament lasted only one year, 1875-76, it provided a model for the Young Turk parliament in 1905. However, the installation of collaborationist officials in Egypt along with the installation of two Europeans permanently sullied 
its authenticity. When Egypt finally broke from Britain in 1952, it would be through an extra parliamentary institution, the army, which had not been so corrupted.

This comparison suggests both Egypt and Turkey underwent broadly similar economic, administrative, military, and political changes throughout the nineteenth century. Both experienced increasing European economic penetration. Infrastructural projects like railroads, telegraphs, and steamships paved the way for British and French power to be physically inscribed on these areas even though formal political power remained in the hands of local elites. As a result of economic penetration, the political influence of European countries and their ability to affect internal decision making in both places increased. This resulted in a situation characterized by mixed sovereignty where multiple parties could plausibly claim decision-making authority over the same areas, but only in Egypt did this bring invasion and occupation. This discrepancy probably occurred because of the geopolitical interests of the European powers, and especially Great Britain to support the Ottoman Porte against Russian incursion even as the Porte weakened geopolitically. Although Egypt and Turkey possessed strong state apparatuses and nascent parliamentary institutions, only Turkey was able to become a democracy thanks to the absence of prolonged foreign occupation.

The preceding examination has alerted us to the importance of viewing the late Ottoman Empire as a crucial period for state building in the Middle East. Although the European mandate has traditionally received the lion's share of attention, the late Ottoman period also has a critical role in our understanding of this phenomenon. Concurrent with a renewed focus on the concept of empire, we must develop a better understanding of what empire entails. The strict separation between empire and state and the tying of state exclusively to nation must be questioned. In the nineteenth century, imperial centers developed tools similar to those of the state including passports, surveys, public health departments, and parliaments. The imperial state represents an intermediate entity between nation-state and empire in that it combines an imperial ideology with state techniques. Both nineteenth-century Egypt and Turkey up until 1878 represent instances of the imperial state. What made the exceptional states (eyelet-i mümtaze) exceptional was not that they exercised semi-autonomous decision-making power, but the fact that both Ottoman bureaucrats and regional rulers cooperated with each other even as both acted to maximize their advantage.

While the ideology of Ottomanism was not successful in the long term, one should not minimize the commitment reformers had for improving governance within an imperial frame. As Ellen Comisso (2006: 141) writes, groups with grievances did not always demand a sovereign state: "Where empires were functioning the most common demand was simply for the chance to participate in the institutions of empire." Although violence should not be scrubbed from the historical record of empire, neither should contemporary observers limit the repertoires of empires to sheer coercion. Concurrently, a teleological rendering whereby empires morph into nation-states as a consequence of pressure from the forces of modernity should likewise be avoided. The earlier ability of the Ottoman Empire as described by Barkey to accommodate variation and flexibility should be extended into the nineteenth century. During this period, the rulers of empire attempted to do this while changing the very basis of rule 
along with the legitimating ideology that accompanied it from a patrimonial one based on the religiously derived authority of the sultan to a rational-legal one based on the rule of law and the equality of individuals and communities. While these reformers were not completely successful, the gains they made given their trying circumstances both internationally and domestically remain notable. Ultimately, one cannot compile an accurate image of the historical period in question without incorporating the ways in which the empire responded to the challenges of the period.

The idea of "bringing the Empire back in" (Evans et al. 1985) in terms of state formation is slowly growing among academics. A book edited by Brown (1997) entitled Imperial Legacies broadly traces the linguistic, cultural, educational, political, and religious impact of the Ottoman Empire on the Balkans and Middle East. Hasan Kayali's Arabs and Young Turks (1997) explores the intersection between Ottomanism and Arab Nationalism at the turn of the twentieth century. However, to obtain a complete picture, we must consider the late Ottoman administration in the Arab periphery to bring a regionwide focus on state formation borrowed from comparative historical sociology that has been slow to expand beyond Europe. A close examination will reveal a fusion of Ottoman, European, and native regional interests combined to create a unique entity. As far as democracy is concerned, its pathway was blocked in regional states like Egypt. The effects of this disruption led to a legacy of despotism and unrest that has continued even in the wake of the ouster of Hosni Mubarak in 2011. If scholarship can reveal what derailed Egyptian democracy in 1883, perhaps a clearer picture will emerge as to how to set it back on its course in the present day.

\section{References}

Akarli, Engin (1993) The Long Peace: Ottoman Lebanon, 1861-1920. Berkeley: University of California Press.

Alon, Yoav (2009) The Making of Jordan: Tribes, Colonialism and the Modern State. London: I.B. Tauris. Altınay, Ayse Gul (2005) The Myth of the Military-Nation: Militarism, Gender, and Education in Turkey. New York: Palgrave Macmillan.

American Society of International Law, trans. (1908) "The Ottoman Constitution," promulgated the 7th Zilbridje, 1293 (11/23 December, 1876). American Journal of International Law 2 (4, Supplement: Official Documents) (20): 368-87.

Anderson, Lisa (1987) The State and Social Transformation in Tunisia and Libya, 1830-1980. Princeton, NJ: Princeton University Press.

Anderson, Perry (1985) Lineages of the Absolutist State. London: Verso.

Aston, T. H., and C. H. E. Philpin, eds. (1987) The Brenner Debate: Agrarian Class Structure and Economic Development in Pre-industrial Europe. Cambridge: Cambridge University Press.

Baer, Gabriel (1962) A History of Landownership in Modern Egypt, 1800-1950. Oxford: Oxford University Press.

Barkey, Karen (1996) Bandits and Bureaucrats: The Ottoman Route to State Centralization. Ithaca, NY: Cornell University Press. (2008) Empire of Difference: The Ottomans in Comparative Perspective. Cambridge: Cambridge University Press.

Baron, Beth (2007) Egypt as a Woman: Nationalism, Gender, and Politics. Berkeley: University of California Press. 
Bhabha, Homi K. (1994) The Location of Culture. London: Routledge.

Bourdieu, Pierre (1993) "The field of Cultural Production or the Economic World Revised." In The Field of Cultural Production: Essays on Art and Literature, edited by Randal Johnson, 29-73. New York, New York: Columbia University Press.

Brown, L. Carl, ed. (1997) Imperial legacy: The Ottoman Imprint on the Balkans and the Middle East. New York: Columbia University Press.

Ceylan, Eyhan (2014) Eyalet-i Mümtaze ve Misır uygulaması. Istanbul, Turkey: Kitabevi.

Chakrabarty, Dipesh (2007) Provincializing Europe: Postcolonial Thought and Historical Difference. Princeton, NJ: Princeton University Press.

Chatterjee, Partha (1993) The Nation and Its Fragments: Colonial and Postcolonial Histories. Princeton, NJ: Princeton University Press.

Clancy-Smith, Julia Ann (1997) Rebel and Saint: Muslim notables, Populist Protest, Colonial Encounters (Algeria and Tunisia, 1800-1904). Berkeley: University of California Press.

Cole, Juan R. I. (1992) Colonialism and Revolution in the Middle East: Social and Cultural Origins of Egypt's Urabi Movement. Princeton, NJ: Princeton University Press.

Comisso, Ellen (2006) "Empires as prisons of nations versus empires as political opportunity structures: An exploration of the role of nationalism in imperial dissolutions in Europe," in Joseph Esherik, Hasan Kayalı, and Eric Van Young (eds.) Empire to Nation: Historical Perspectives on the Making of the Modern World. Lanham, MD: Rowman and Littlefield: 138-67.

Connell, Raewyn (2007) Southern Theory: Social Science and the Global Dynamics of Knowledge. Cambridge: Polity Press.

Cooper, Frederick (2005) Colonialism in Question: Theory, Knowledge, History. Palo Alto, CA: Stanford University Press.

Davison, Roderic H. (1973) Reform in the Ottoman Empire, 1856-1876. New York: Gordian Press.

(1979) "Nationalism as an Ottoman problem and the Ottoman response," in William H. Haddad and William Ochsenwald (eds.) Nationalism in a Non-national State: The Dissolution of the Ottoman Empire. Columbus: Ohio State University Press: 25-56.

Deringil, Selim (2011) The Well-Protected Domains: Ideology and the Legitimation of Power in the Ottoman Empire, 1876-1909. London: I. B. Tauris.

Dodge, Toby (2010) Inventing Iraq: The Failure of Nation Building and a History Denied. London: C. Hurst.

Elias, Norbert (2000) The Civilizing Process: Sociogenetic and Psychogenetic Investigations. Oxford: Blackwell Publishing.

Endelman, Jonathan (2015) "Displaying the State: Visual Signs and Colonial Construction in Jordan." Theory and Society 44 (3): 199-218.

Evans, Peter B., Dietrich Rueschemeyer, and Theda Skocpol, eds. (1985) Bringing the State Back In. Cambridge: Cambridge University Press.

Fahmy, Khaled (2002) All the Pasha's Men: Mehmed Ali, His Army and the Making of Modern Egypt. Cairo: American University in Cairo Press

Fahmy, Ziad (2011) Ordinary Egyptians: Creating the Modern Nation through Popular Culture. Palo Alto, CA: Stanford University Press.

Fawaz, Leila (1994) An Occasion for War: Civil Conflict in Lebanon and Damascus in 1860. Berkeley: University of California Press.

Fieldhouse, David Kenneth (2006) Western Imperialism in the Middle East: 1914-1958. Oxford: Oxford University Press.

Findley, Carter Vaughn (1980) Bureaucratic Reform in the Ottoman Empire: The Sublime Porte, 17891922. Princeton, NJ: Princeton University Press.

Fortna, Benjamin C. (2002) Imperial Classroom: Islam, the State, and Education in the Late Ottoman Empire. New York: Oxford University Press.

Foucault, Michel (1998) "Security, territory, and population," in Essential Works of Foucault, 1954-1984. Vol. 1, Ethics: Subjectivity, and Truth. New York: New Press: 67-73. 
Go, Julian (2008) American Empire and the Politics of Meaning: Elite Political Cultures in the Philippines and Puerto Rico during US Colonialism. Durham, NC: Duke University Press.

Göçek, Fatma Mudge (1987) East Encounters West: France and the Ottoman Empire in the Eighteenth Century. New York: Oxford University Press.

(2008) "What is the meaning of the Young Turk revolution? A critical historical assessment in 2008.” Istanbul University Political Science Faculty Journal 38: March: 179-214.

Goldstone, Jack A. (1993) Revolution and Rebellion in the Early Modern World. Berkeley: University of California Press.

Hanioğlu, M. Sukru (2010) A Brief History of the Late Ottoman Empire. Princeton, NJ: Princeton University Press.

Hourani, Albert (1969) "Ottoman reform and the politics of notables," in W. R. Polk and R. L. Chambers (eds.) Beginnings of Modernization in the Middle East: Nineteenth Century. Chicago: University of Chicago Press: 41-68.

Hunter, F. Robert (1999) Egypt under the Khedives: 1805-1879: From Household Government to Modern Bureaucracy. Cairo: American University in Cairo Press.

Ikegami, Eiko (1997) The Taming of the Samurai: Honorific Individualism and the Making of Modern Japan. Cambridge, MA: Harvard University Press.

Inalcik, Halil (1976) Application of the Tanzimat and Its Social Effects. Lisse, The Netherlands: De Ridder Press.

James, C. L. R. (1989) The Black Jacobins: Toussaint L'Ouverture and the San Domingo Revolution. New York: Vintage.

Karal, Enver Ziya (1976) "Önsöz.” In Üç Tarz-1 Siyaset, by Yusuf Akçura, 1-18. Vol. 73. Türk Tarih Kurumu Yayınları. Ankara, Turkey: Türk Tarih Kurumu Basımevi.

Kasaba, Reşat (2006) "Dreams of empire, dreams of nations," in Joseph Esherick, Hasan Kayalı, and Erick Van Young (eds.) Empire to Nation: Historical Perspectives on the Making of the Modern World. Lanham, MD: Rowman and Littlefield: 198-225.

Kayali, Hasan (1997) Arabs and Young Turks: Ottomanism, Arabism, and Islamism in the Ottoman Empire, 1908-1918. Berkeley: University of California Press.

Mann, Michael (2005) The Dark Side of Democracy: Explaining Ethnic Cleansing. Cambridge: Cambridge University Press.

Mardin, Şerif (2000) The Genesis of Young Ottoman Thought: A Study in the Modernization of Turkish Political Ideas. Syracuse, NY: Syracuse University Press.

Marsot, Alaf L. A.-S. (1984) Egypt in the Reign of Muhammad Ali. Cambridge: Cambridge University Press.

Millman, Richard “The Bulgarian Massacres Reconsidered," The Slavonic and East European Review (58) 2 (1980): 218-231

Mitchell, Timothy (1991) Colonising Egypt. Berkeley: University of California Press.

Moore, Barrington (1993) Social Origins of Dictatorship and Democracy: Lord and Peasant in the Making of the Modern World. Boston: Beacon Press.

Neep, Daniel (2012) Occupying Syria under the French Mandate: Insurgency, Space, and State Formation. Cambridge: Cambridge University Press.

Ortaylı, Ilber (2005) Imparatorlugŭn en uzun yüzyılı. Istanbul, Turkey: Iletişim Yayınları.

Owen, E. R. J. (1969) Cotton and the Egyptian Economy, 1820-1914: A Study in Trade and Development. Oxford: Oxford University Press.

Ozekicioglu, Seda and Ozekicioglu, Halil (2010) "First borrowing period at Ottoman Empire (1854-1876): Budget policies and consequences", Business and Economic Horizons 3(3): 28-46.

Quataert, Donald (1993) Ottoman Manufacturing in the Age of the Industrial Revolution. Cambridge: Cambridge University Press.

Rodogno, Davide (2011) Against Massacre: Humanitarian Interventions in the Ottoman Empire, 18151914. Princeton, New Jersey: Princeton University Press.

Rodrigue, Aaron (1995) "Difference and tolerance in the Ottoman Empire: Interview by Nancy Reynolds." Stanford Humanities Review 5 (1): 81-92. 
Safran, Nadav (1991) Saudi Arabia: The Ceaseless Quest for Security. Ithaca: Cornell University Press.

Salzmann, Ariel (1999) "Citizens in search of a state: The limits of political participation in the late Ottoman Empire, 1808-1914," in Michael Hanagen and Charles Tilly (eds.) Extending Citizenship, Reconfiguring States. Lanham, MD: Rowman and Littlefield: 37-66.

(2004) Tocqueville in the Ottoman Empire: Rival Paths to the Modern State. Leiden, The Netherlands, and Boston: Brill.

Schölch, Alexander (1981) Egypt for the Egyptians! The Socio-Political Crisis in Egypt, 1878-1882; St. Antony's Middle East Monographs 14. London: Ithaca Press.

Scott, James C. (1992) Domination and the Arts of Resistance: Hidden Transcripts. New Haven, CT: Yale University Press.

(1999) Seeing Like a State: How Certain Schemes to Improve the Human Condition Have Failed. New Haven, CT: Yale University Press.

Sharkey, Heather J. (2003) Living with Colonialism: Nationalism and Culture in the Anglo-Egyptian Sudan. Berkeley, CA: University of California Press.

Skocpol, Theda (1979) States and Social Revolutions: A Comparative Analysis of France, Russia and China. Cambridge, MA: Cambridge University Press.

Sohrabi, Nader (2002) "Global waves, local actors: What the Young Turks knew about other revolutions and why it mattered." Comparative Studies in Society and History 44 (1): 45-79.

(2011) Revolution and Constitutionalism in the Ottoman Empire and Iran. Cambridge: Cambridge University Press.

Sohrabi, Nader (2011) Revolution and constitutionalism in the Ottoman Empire and Iran, 1902-1910. Cambridge, England: Cambridge University Press.

Stokes, Susan C., Thad Dunning, Marcelo Nazareno, and Valeria Brusco (2013) Brokers, Voters, and Clientelism: The Puzzle of Distributive Politics. Cambridge: Cambridge University Press.

"The Ottoman Constitution, Promulgated the 7th Zilbridje, 1293 (11/23 December, 1876)." The American Journal of International Law 2 (4) (1908): 367.

Tilly, Charles (1992) Coercion, Capital and European States: AD 990-1992. Oxford: Wiley-Blackwell.

Tocqueville, Alexis de (2008 [1856]) Ancien Regime and the French Revolution. New York: Penguin.

Toledano, Ehud R. (2003) State and Society in Mid-Nineteenth-Century Egypt. Cambridge: Cambridge University Press.

Uzunçarşıll, I. H. (1983) “Misir velisi Mehmed Ali Paşa kuvvetleri tarafindan Saruhan, Aydin, ve lzmir'in dair vesikalar." Turk Tarih Kurumu Belleten 47 (185): 29.

Virginia H. Aksan (2005/2006) Ottoman to Turk: Continuity and Change, International Journal 61 (1): Turkey: Myths and Realities: 19-38.

Wallerstein, Immanuel (2011) The Modern World-System: Capitalist Agriculture and the Origins of the European World-Economy in the Sixteenth Century. Berkeley: University of California Press.

Weber, Max (1958) "Politics as a vocation," in H. H. Gerth and C. W. Mills (eds.) From Max Weber: Essays in Sociology. Oxford: Oxford University Press: 77-129. 